\title{
ENTRE LIÇÕES E COMPOSIÇÕES: ESTUDOS SOBRE CRÍTICA LITERÁRIA COM BASE EM IMPRESSÕES DO PÚBLICO INFANTO- JUVENIL SOBRE O LIVRO A VELHINHA QUE DAVA NOME ÀS COISAS
}

\author{
Airton Pott* \\ Ivânia Campigotto Aquino**
}

\begin{abstract}
RESUMO: Todo leitor constrói impressões a partir da realização da leitura de algum texto, e isso não é exceção para o público infanto-juvenil. Escrever um texto, sobretudo literário, para as crianças envolve criatividade diferenciada, organização dos fatos, estética emancipatória. Sob essas considerações, almejamos, neste trabalho, verificar as percepções e impressões de crianças leitoras a respeito de uma obra infanto-juvenil usada em sala de aula ao longo do ano letivo como meio de ensino e aprendizagem. Para tanto, selecionamos a obra A velhinha que dava nome às coisas, de Cynthia Rylant, para complementarmos os estudos sobre os substantivos em uma turma de $6^{\circ}$ ano do Ensino Fundamental de uma escola pública e, a partir de tais estudos, averiguarmos a criticidade dos alunos e o que mais chama a atenção deles em um livro. Ancoramos a análise nas teorias do efeito estético de Iser (1999), bem como na teoria da recepção de Jauss (1994) e Zilberman (1989) e, ainda, nos estudos realizados por Petit (2008), relacionados à leitura. Essas linhas teóricas nos possibilitam inúmeras e interessantes conclusões voltadas à leitura e à recepção das obras, das quais convém destacar a importância da relação entre a forma e o conteúdo.
\end{abstract}

ABSTRACT: Every reader builds impressions from reading some text, and this is no exception for children and adolescents. Writing a text, especially literary, for children involves differentiated creativity, organization of facts, emancipatory aesthetics. Under these considerations, we aim, in this work, to verify the perceptions and impressions of children readers about a children's work used in the classroom throughout the school year as a means of teaching and learning. For this purpose, we selected the work A velhinha que dava nome às coisas, by Cynthia Rylant, to complement the studies on nouns in a 6th grade class in a public school and, based on such studies, to verify the criticality of students and what most catches their attention in a book. We are anchored in the theories of the aesthetic effect of Iser (1999), as well as the theory of reception by Jauss (1994) and Zilberman (1989) and also by studies carried out by Petit (2008), related to reading. These theoretical lines allow us to countless and interesting conclusions focused on the reading and reception of works, of which it is important to highlight the importance of the relationship between form and content.

PALAVRAS-CHAVE: Literatura infanto-juvenil. Leitura. Recepção.

KEYWORDS: Children and youth literature. Reading. Reception.

\section{CONSIDERAÇÕES INICIAIS: ASPECTOS METODOLÓGICOS}

$\mathrm{Na}$ perspectiva das teorias do efeito estético e da recepção, indagamos sobre as percepções do público infanto-juvenil a respeito do livro A velhinha que dava nome às coisas, de Cynthia Rylant, publicado em 2002. Como se dá a recepção de uma obra por parte das crianças e dos jovens com base nas lições pretendidas pelo autor por meio daquele texto e como isto está atrelado à composição da obra?

INTERLETRAS, ISSN $N^{o}$ 1807-1597. V. 9, Edição número 34. Outubro, 2021/ Março de 2022- p

Dossiê: Educação, infância, diversidade e ensino de língua em contexto complexo. 
Mediante o intuito de fazer essa sondagem, foi desenvolvida uma sequência didática que coloca o livro no centro das atividades. A aula foi desenvolvida em uma turma de $6^{\circ}$ ano do Ensino Fundamental de uma escola pública do noroeste do estado do Rio Grande do Sul no ano de $2018^{1}$. Inicialmente, foi projetada, pelo aparelho multimídia, a narrativa $A$ velhinha que dava nome às coisas, a qual foi lida e, a partir disso, fez-se uma explanação oral a respeito da história. Depois, foi proposto aos alunos que nomeassem, escolhendo substantivos próprios, no mínimo 10 objetos comuns e, a partir disso, criassem charadas. A outra atividade inspirada no livro consistia na produção textual de uma narração que contivesse alguns dos nomes próprios nos lugares dos objetos comuns, assim como no livro lido.

Salientamos, porém, que, para este estudo, interessa-nos analisar apenas as considerações dos alunos a partir de duas perguntas lançadas a eles após alguns meses da realização da atividade, a fim de verificar o que lembravam da história. Nesse sentido, a escrita que consideramos aqui, para análise, parte de duas questões: 1) O que chamou a atenção na história, no livro?; 2). Quais as impressões que tiveram sobre a história e sobre as atividades a partir dela?

As perguntas norteadoras visaram compreender, com o mínimo de interferências e influências, as impressões que os alunos tiveram, bem como reações e lembranças, haja vista que as perguntas foram aplicadas meses depois, aliás, no ano seguinte, o que reforça ainda mais as marcas da história e das atividades realizadas a partir dela. Os estudos analíticos a respeito de tais comentários dos alunos são fundamentados na teoria da estética da recepção de Jauss (1994), e que são reforçados por Zilberman (1989).

Associamos a esses estudos a teoria do efeito estético de Iser (1999), que nos remete às considerações sobre a obra, o texto. Afinal, sem texto não há leitor, e sem leitor o texto não se atualiza, não tem significação de sua existência. Dessa forma, reforçamos que a teoria do efeito estético visa fundamentar, principalmente, a relação entre texto e leitor, e quais estratégias encontradas em uma obra e que ganham notoriedade por aquele que a recebe, a lê.

Diante do fato de o público leitor da obra abordada ser infanto-juvenil, também nos amparamos nos estudos de Petit (2008) a respeito da leitura e dos jovens. Portanto, tecemos considerações e relações entre essas diferentes teorias que, em nossos estudos, enquadram-se em nosso delineamento temático. Posteriormente, expomos uma breve apresentação da obra e, por último, as análises de comentários escritos por alguns alunos, seguidos das considerações finais.

\section{A RELAÇÃO DE INTERDEPENDÊNCIA ENTRE O AUTOR, A OBRA E O LEITOR}

\footnotetext{
${ }^{1}$ Frisamos que nossos estudos não consistiam em um plano de aula abrangente, pois nossa intenção foi de obter subsídios para realizar estudos voltados às compreensões dos alunos a respeito do livro, e não enfocar o plano de aula em si. INTERLETRAS, ISSN N $N^{\circ}$ 1807-1597. V. 9, Edição número 34. Outubro, 2021/ Março de 2022- p
}

Dossiê: Educação, infância, diversidade e ensino de língua em contexto complexo. 
Partimos da premissa de que sem texto não há leitor e de que não faz sentido existir um texto se ele não tiver um público que o lê, e é assim que se constitui a relação de interdependência entre ambos. Além do mais, não podemos nos esquecer que por trás de um texto está um autor. Portanto, também o autor precisa do texto para conseguir se comunicar e do leitor para realizar a leitura e atualizá-la conforme suas impressões e interpretações.

Para muitos, o ato de leitura pode parecer apenas a decodificação de informações lançadas por um autor. No entanto, o leitor é sujeito tão ativo quanto o autor no processo de comunicação por meio de um texto. As funções, porém, são outras, pois enquanto o autor escreve um texto, inclusive pensando em seu público leitor, este recebe e atualiza as informações contidas nele, conforme seu conhecimento, suas vivências e experiências.

Apoiamos essas considerações em Iser (1999, p. 97), na ideia que "sendo uma atividade guiada pelo texto, a leitura acopla o processamento do texto com o leitor; este, por sua vez, é afetado por tal processo. Gostaríamos de chamar tal relação recíproca de interação.”. Parece simples e ao mesmo tempo mágico, mas o texto é o conector entre dois sujeitos que estão em diferentes espaços e tempos, e não precisa de wi-fi, celular, notebook ou outro aparelho eletrônico, se o mesmo estiver impresso ou ter sido escrito manualmente.

Além disso, em uma composição do livro também estão a qualidade de uma obra literária, tanto da categoria escrita quanto da imagética, e demais aspectos composicionais. Assim, para ampliar nossa compreensão a respeito dessa questão, recorremos às concepções de Jauss (1994, p. 07-08):

Afinal, a qualidade e a categoria de uma obra literária não resultam nem das condições históricas ou biográficas de seu nascimento, nem tão-somente de seu posicionamento no contexto sucessório do desenvolvimento de um gênero, mas sim dos critérios da recepção, do efeito produzido pela obra e de sua fama junto à posteridade, critérios estes de mais difícil apreensão.

Dado o exposto, na perspectiva da estética da recepção, tanto o conteúdo quanto a forma são essenciais para influenciar nas sensações despertadas pelo texto aos seus leitores. É natural que os leitores apreciem uma bela história, uma bela leitura, mas não se conscientizam do que tudo está envolvido ali. Os leitores mais desatentos tendem a não perceber que não é apenas a temática da história que lhe despertou prazer, mas sim sua formação e composição. Logo, é nisso que consiste a teoria do efeito estético de Iser (1999, p. 144), de que "a estrutura, contudo, permanece constante, sendo matriz elementar para a interação entre texto e leitor".

O texto como um todo - sua estrutura, suas palavras, sua estética - contribuem para que o leitor o receba da melhor forma pretendida pelo autor, o qual muitas vezes escreve para um determinado público. No entanto, é o leitor quem recebe a obra e, conforme Zilberman $(1989$, p. 21), "é o recebedor que transforma a obra, até então mero artefato, em objeto

INTERLETRAS, ISSN $N^{\circ}$ 1807-1597. V. 9, Edição número 34. Outubro, 2021/ Março de 2022- p

Dossiê: Educação, infância, diversidade e ensino de língua em contexto complexo. 
estético, ao decodificar os significados transmitidos por ela.". Em outras palavras, o leitor é o sujeito ativo e em transformação no ato da leitura.

Logo, ao pensarmos no texto ficcional, percebemos, então, que "a literatura como acontecimento cumpre-se primordialmente no horizonte de expectativa dos leitores, críticos e autores, seus contemporâneos e pósteros, ao experienciar a obra. " (JAUSS, 1994, p. 26). Nessa perspectiva, podemos inferir que o horizonte de expectativas dos leitores é formado também pelo significado da obra e também pela sua composição estrutural, sua estética. Nas palavras de Zilberman (1989, p. 26):

O significado da obra depende totalmente dos sentidos que o leitor deposita nela. Também seu caráter estético depende do destinatário: se este não o vivencia como obra de arte e busca aí outro tipo de experiência (uma informação, por exemplo), o texto perde sua qualidade artística.

Indubitavelmente, o livro literário é uma obra de arte, mas assim como uma escultura, uma pintura, ele pode ser "um caminho privilegiado para se construir, se pensar, dar um sentido à própria experiência, à própria vida; para dar voz a seu sofrimento, dar forma a seus desejos e sonhos." (PETIT, 2008, p. 72). Dessa forma, o texto é o elo que liga, em tese, parte do conhecimento e das experiências do autor do texto com as do leitor. Afinal, o autor, ao escrever o texto, imagina seu público leitor e o que ele quer ler ou que, segundo o escritor, precisa ler.

Em linhas gerais, a obra literária, em sua proposição recepcional, “ [...] é, antes, como uma partitura voltada para a ressonância sempre renovada da leitura, libertando o texto da matéria das palavras e conferindo-lhe existência atual [...]". (JAUSS, 1994, p. 25). Desse modo, o eu constituinte do leitor influencia na interpretação e na compreensão da leitura, e o texto literário, com seu caráter multissignificativo, contribui para que cada leitor imprima ao texto sua própria e única leitura.

No entanto, o leitor não tem total liberdade diante do texto, ele não pode interpretar e compreender o que quiser, pois o texto possui norteamento e delineamento de informações. Por exemplo, comumente os leitores se sensibilizam com os heróis, os mocinhos, e se enraivecem com os vilões, os antagonistas. Isso, porém, não ocorre por livre e espontânea vontade deles, mas sim porque são levados a isso pela exposição dos fatos e pela sensibilização tencionada pelo autor do texto.

Além do mais, também o autor não tem total liberdade para criar despreocupadamente. Afinal, ele tem um público do qual ele precisa, senão seu texto não sobrevive, não ganha extensão e expansão, isto é, cai no esquecimento. Dessa maneira, também o autor precisa pensar no outro e fazer escolhas. De acordo com Zilberman (1989, p. 59), "a escolha do herói não é aleatória [...]. Os heróis se definem, portanto, não apenas por suas ações, mas pelas respostas desencadeadas no público, razão pela qual vêm a constituir o fio teórico escolhido pelo Autor.".

O texto, escrito e delimitado pelas escolhas do autor, "[...]conduz o leitor a determinada postura emocional [...]. " (JAUSS, 1994, p. 28). Sendo assim, as informações estão INTERLETRAS, ISSN No 1807-1597. V. 9, Edição número 34. Outubro, 2021/ Março de 2022- p

Dossiê: Educação, infância, diversidade e ensino de língua em contexto complexo. 
interpeladas pela subjetividade da interpretação, assim como os diferentes gostos dos diversos leitores almejados pelo autor do texto. Afinal de contas, assim como ao autor é possibilitado a realização de escolhas, o leitor também pode fazê-las. Nessas circunstâncias,

O leitor não é passivo, ele opera um trabalho produtivo, ele reescreve. Altera o sentido, faz o que bem entende, distorce, reemprega, introduz variantes, deixa de lado os usos corretos. Mas ele também é transformado: encontra algo que não esperava e não sabe nunca aonde isso poderá levá-lo. (PETIT, 2008, p. 29).

O aspecto de descoberta atrelado à obra literária influencia o leitor, curioso, a permanecer na leitura não apenas pelo fato de identificar-se com a história, ou gostar de ler, ou buscar informações e conhecimento, mas também porque não sabe o que acontecerá com os personagens. Ainda mais diante do fato de que por mais surreal e fictícia que pareça a história narrada no texto literário, alguma semelhança com a realidade é estabelecida. De acordo com Zilberman (1989, p. 100), "o modo como a obra se apropria dos elementos do cotidiano e reelabora-os artisticamente indica seus contatos com a sociedade.".

Em um livro infantil, por exemplo, é fácil encontrarmos elementos e personagens que no mundo real são impossíveis de existir, pelo menos com aquelas características. Um dos mais típicos exemplos são o de inúmeras fábulas que possuem animais falantes como personagens. Enfim, sabemos que eles não existem na realidade, mas sabemos que existe a fala e que existem animais.

Diante dessa reinvenção da realidade e da sociedade no mundo ficcional por meio da literatura, somos inclinados a concordar com Petit (2008, p. 79) no que se refere à ideia de que "os livros, e em particular os de ficção, nos abrem as portas para um outro espaço, para uma outra maneira de pertencer ao mundo. Os escritores nos presenteiam com uma geografia, uma história, uma paisagem onde retomamos o fôlego. "

Outrossim, os escritores de histórias infantis tentam conquistar as crianças aproximandose delas por meio dos textos que contém personagens e demais elementos dos quais elas têm tendência a gostarem. Afinal, as crianças também já possuem gostos, senso crítico e capacidade de escolha e argumentação. Dessa forma, quando o autor quer passar alguma lição de moral, ele faz isso implicitamente em seu texto literário, aliando o prazer da leitura ao aprendizado das crianças.

É, portanto, na tentativa de agradar às crianças, de corresponder ao horizonte de expectativas do leitor infantil, que o autor conta com ilustradores para auxiliarem no embelezamento estético de sua obra literária a partir de elementos não-verbais. Tais preceitos já são ratificados por Iser (1999, p. 150): “o livro infantil contendo ilustrações tende a conquistar mais facilmente os alunos, pois além de o aluno imaginar a história a partir da escrita, ele tem o recurso não-verbal para auxiliá-lo nesse processo.

Passar conhecimento e prazer de ler é um propósito essencial por autores e ilustradores de livros infantis. No entanto, para conseguir aliar um ao outro é imprescindível que se INTERLETRAS, ISSN $N^{o}$ 1807-1597. V. 9, Edição número 34. Outubro, 2021/ Março de 2022- p

Dossiê: Educação, infância, diversidade e ensino de língua em contexto complexo. 
pense na imaginação do público infantil, uma vez que ninguém nasce falando ou fazendo uso da imaginação, pois esta é vazia no recém-nascido. Sendo assim, é na tentativa de instigar a imaginação que também se encontra um propósito dos livros infantis. Para Petit (2008, p. 179), “o imaginário não é algo com que se nasce. É algo que se elabora, se desenvolve, se enriquece, se trabalha, ao longo dos encontros.".

Ademais, o texto literário, sobretudo infantil, também tem em si o intuito de estabelecer ensinamentos e relações com os aspectos sociais do mundo real. Além de ensinar, possibilitar conforto, refúgio, e despertar a imaginação, a obra infantil visa contribuir para a vida social e interacional do receptor dela. Já salientava Jauss (1994, p. 57) que "[...] se deve buscar a contribuição específica da literatura para a vida social precisamente onde a literatura não se esgota na função de uma arte de representação.”.

Essa arte de representação da realidade é o elo de ligação entre uma história ficcional e a realidade social. Em uma obra literária há uma gama de possibilidades e estratégias articuladas por um autor que endereça a seus possíveis leitores parte do que ele externa de sua imaginação. Mas na busca do ensinamento a outros, também ele é modificado.

Dessa forma, tanto a escrita de um texto quanto a leitura têm seus atos voltados aos fatores interacionais e sociais. Segundo Petit (2008, p. 100),

\begin{abstract}
A leitura contribui assim para criar um pouco de "jogo" no tabuleiro social, para que os jovens se tornem um pouco mais atores de suas vidas, um pouco mais donos de seus destinos e não somente objetos do discurso dos outros. Ajuda-os a sair dos lugares prescritos, a se diferenciar dos rótulos estigmatizantes que os excluem, e também das expectativas dos pais ou dos amigos, ou mesmo do que cada um deles acreditava, até então, que era o mais adequado para o definir.
\end{abstract}

Dado o exposto, ressalvamos que o livro é, muitas vezes, o lugar onde o leitor encontra as respostas, um escape da vida real, e onde descobre o novo. Logo, ao realizar a leitura, o sujeito, seja qual for sua faixa etária, tem autonomia para imaginar, inventar, ressignificar, decidir, ou seja, ser sujeito com capacidade de agir conforme seus princípios e suas vontades e, assim, obter suas próprias e individuais percepções.

Não raramente o leitor envolve-se tão profundamente com a história que está lendo que parece fazer parte daquilo, e não só naquele momento. Por exemplo, quando uma criança desenha a si ou seus pais como heróis, ela não inventou isso simplesmente do nada. Ela teve a capacidade de assimilar informações, ou seja, que gostaria que ela e seus pais fossem heróis, ou então já enxerga eles como sendo uns e resolveu fazer essa representação unindo os heróis da vida real com os do mundo ficcional.

Nesse contexto, "com efeito, captamos um texto ficcional quando entendemos o que as representações por ele estimuladas querem dizer." (ISER, 1999, p. 140). Essas compreensões tornam-se possíveis graças à capacidade de assimilação, interpretação e imaginação dos leitores. A leitura é, portanto, uma eloquente forma de aprendizados e interação entre sujeitos.

INTERLETRAS, ISSN $N^{\circ}$ 1807-1597. V. 9, Edição número 34. Outubro, 2021/ Março de 2022- p

Dossiê: Educação, infância, diversidade e ensino de língua em contexto complexo. 
Além do mais, os livros são guardadores de informações e guiadores de argumentações. Quando dois ou mais leitores de uma mesma obra literária se encontram eles podem trocar informações a partir de suas leituras. "Esta abertura para o outro, que é consequência da leitura, também adota, muito concretamente, novas formas de sociabilidade, de partilhar e de conversar em torno dos livros. " (PETIT, 2008, p. 97).

Quando um assunto entre duas ou mais pessoas está relacionado a um determinado livro ou texto literário, diferentes pontos de vista podem ser contrastados em torno daquela leitura. Zilberman $(1989$, p. 34) já ressaltava que "cada leitor pode reagir individualmente a um texto, mas a recepção é um fato social - uma medida comum localizada entre essas reações particulares [...].”.

Nessa socialização de experiências a respeito de um livro ocorre algo semelhante àquela tensão causada quando o leitor está lendo e fica na expectativa de descobrir o que ainda não sabe e só desvendará se persistir na leitura. A esse respeito, encontramos respaldo às considerações em Iser (1999, p. 140), quando ele explica que "o efeito causado pela tensão nos faz imaginar a informação por ora não dada sobre a continuação da trama. Ao levantar perguntas como 'o que acontecerá? ', intensificamos nossa participação nos acontecimentos".

Enfim, o processo de descoberta e desvendamento por meio da leitura está imbricado aos conflitos não só ficcionais, mas também reais. A socialização a respeito das diferentes percepções sobre a história e seus conflitos, sua trama, desencadeia uma teia de compartilhamento de opiniões e argumentações. Segundo Petit (2008, p. 101), "por meio da difusão da leitura, cria-se um certo número de condições propícias para o exercício ativo da cidadania. Propícias, necessárias, mas não suficientes. "(PETIT, 2008, p. 101).

Portanto, julgamos pertinente e fundamental a investigação a respeito do processo de leitura de um texto literário. Para tal fim, selecionamos um livro infantil que visasse ao exercício ativo da cidadania e realizamos algumas atividades a respeito desse livro com alguns alunos de uma escola pública a fim de coletarmos informações a respeito das impressões que eles tiveram com a história e o que mais lhes chamou atenção nela. Dispomos e analisamos, a seguir, alguns dos resultados a respeito das recepções feitas por alguns desses alunos.

\section{DE CYNTHIA RYLANT ÀS CRIANÇAS: PERCEPÇÕES DOS ALUNOS RECEPTORES DE A VELHINHA QUE DAVA NOME ÀS COISAS}

Condizente com os estudos gramaticais programados nos planos de estudos, o livro $A$ velhinha que dava nome às coisas, da escritora norte-americana Cynthia Rylant, possui ensinamentos sobre substantivos comuns e próprios ao longo de seu enredo. No entanto, a história não tem por único objetivo o de fazer a troca de substantivos comuns batizados com nomes próprios pela protagonista da história.

INTERLETRAS, ISSN $N^{\circ}$ 1807-1597. V. 9, Edição número 34. Outubro, 2021/ Março de 2022- p

Dossiê: Educação, infância, diversidade e ensino de língua em contexto complexo. 
A velhinha que dava nome às coisas é um livro de literatura infantil que possui uma bela história envolvendo a personagem principal - uma velhinha que mora sozinha e já perdeu seus amigos, e objetos que ela nomeia com nomes próprios. Seu carro, por exemplo, ela chama de Beto. Já sua cama, ela nomeou de Belinha, e assim também outros elementos inanimados foram recebendo nomes próprios por aquela anciã.

O conflito principal da história surge, porém, mediante o fato de ela não nomear nenhum ser vivo devido ao medo que ela tinha de perder mais um ente querido. No entanto, eis que surge um cachorro marrom no quintal da casa da velhinha. Ela sente pena dele, dálhe comida, mas não o adota e nem lhe dá um nome, pois ela teme que o cachorrinho não viva mais do que ela.

Os dias passam e o cachorro continua aparecendo no quintal da casa da velhinha, mas ela não o deixa ficar ali. Até que, depois de um tempo, o cachorro não aparece mais. A velhinha começa a ficar preocupada com a falta de retorno do cachorro sem nome e resolve ir à busca dele. Depois de um tempo, encontra-o em um canil, onde ela o batiza de Sortudo em homenagem à sorte que ela reconhece ter em encontrar um novo amigo. Ambos voltam para casa e são felizes em seu lar.

Toda essa história emocionante nos ensina sobre os valores e a amizade. Ela é uma verdadeira lição de vida. Para tanto, a autora vale-se de trocas entre nomes comuns e próprios para narrar tal história. Portanto, temos forma e conteúdo atrelados em si para tornar a história interessante e com seu diferencial único. Uma aula sobre gramática. Uma aula sobre aspectos da vida e da sociedade.

Nessa perspectiva, temos na literatura uma interpretação do mundo real, por meio das histórias, da lição de moral e, portanto, uma pluralidade de finalidades e possibilidades no texto literário. É justamente a percepção dessa multissignificação da literatura que buscamos averiguar nos comentários dos alunos. Para fins analíticos, selecionamos os comentários que apresentassem informações relevantes e significativas tendo em vista as questões elaboradas e, portanto, descartamos aqueles textos cujas ideias eram repetitivas ou irrelevantes.

Dessa forma, analisamos e comentamos algumas das respostas, com o intuito, conforme já evidenciamos, de compreendermos como são as reações e impressões dos leitores infantis e o que lhes desperta atenção em uma obra.

Fig. 1 - Registros escritos do sujeito 01

INTERLETRAS, ISSN No 1807-1597. V. 9, Edição número 34. Outubro, 2021/ Março de 2022- p

Dossiê: Educação, infância, diversidade e ensino de língua em contexto complexo. 


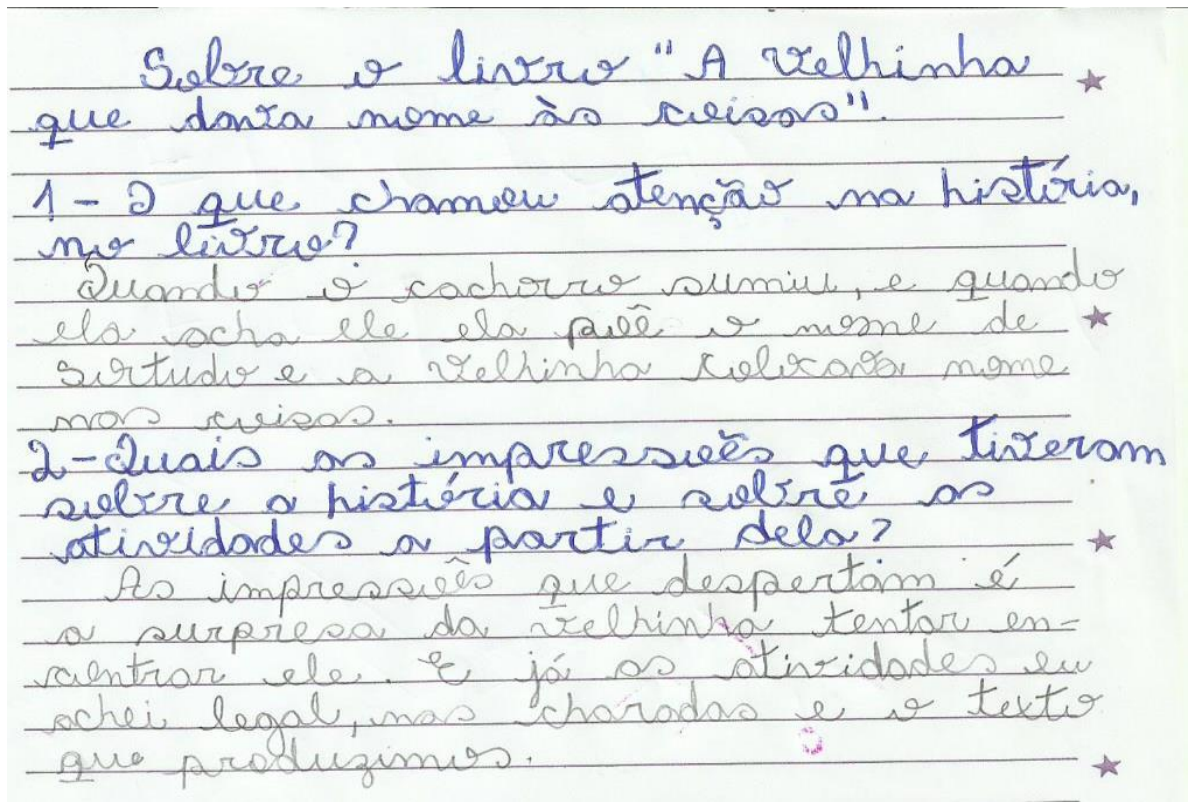

Fonte: digitalização dos manuscritos do sujeito 01 feitos em sala de aula e entregues ao professor.

Verificamos nas duas respostas desse aluno que a ênfase da história que lhe sobressai é a respeito do conflito principal, ou seja, do sumiço do cachorro, e de que, surpreendentemente, a velhinha tenta encontrá-lo e, quando o encontra, dá-lhe um nome. Percebemos, então, que o que mais impressionou a esse aluno foi a história em si, ou seja, os acontecimentos distribuídos, devidamente, no enredo.

No entanto, está implícita, em suas respostas, a relação da classe gramatical dos nomes substantivos. Dessa forma, percebemos, através do comentário desse aluno, que ele possui compreensão do uso dessa classe gramatical na história, bem como em seu comentário. Em outras palavras, esse aluno demonstrou aplicação e adequado uso da gramática em seus textos, sem usar a nomenclatura gramatical.

As respostas desse aluno também despertaram nossa atenção devido ao fato de em ambas as respostas o aluno usar o diminutivo ao referir-se à protagonista da história. Tais repetições nos levam a inferir que a palavra "velha" não soaria tão bem aos ouvidos do leitor quanto seu diminutivo, o que provavelmente fora pensado pela autora.

Parece-nos que esse aluno leitor compreendeu, mesmo que inconscientemente, que a palavra "velhinha" contribuiu para a sensibilização da história para com o leitor, já que a história possui um enredo envolvente e emocionante.

Fig. 2 - Registros escritos do sujeito 02 

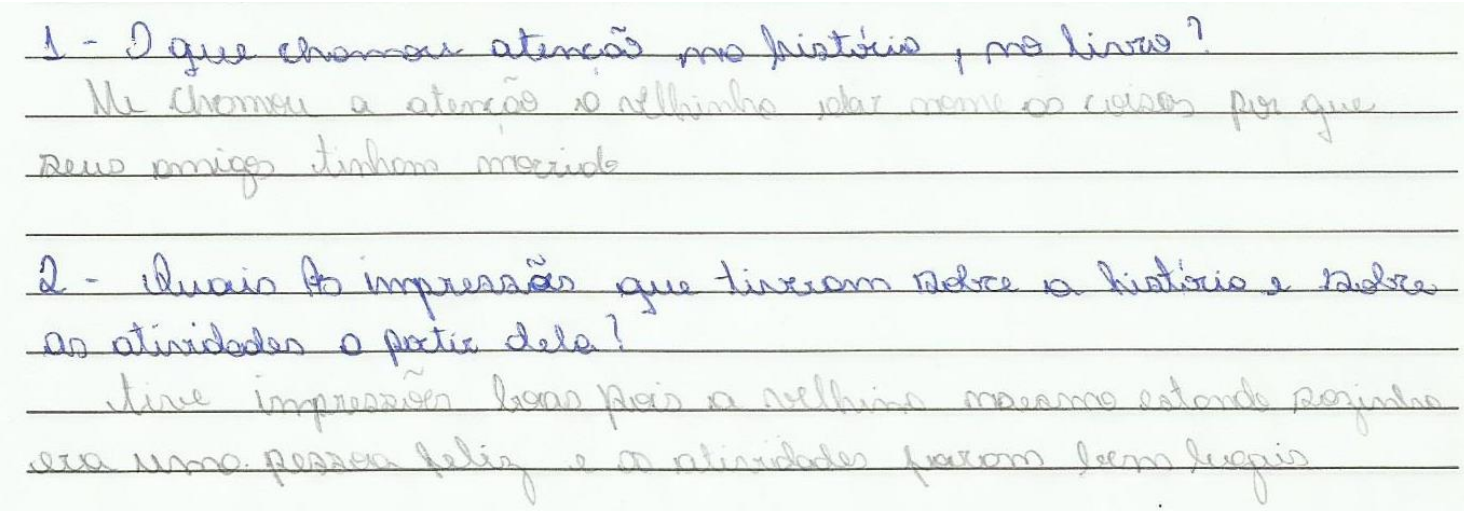

Fonte: digitalização dos manuscritos do sujeito 02 feitos em sala de aula e entregues ao professor.

Assim como nos comentários do sujeito anterior, também este mostrou sensibilização mediante ao fato da solidão da velhinha. No entanto, enquanto o sujeito um enfatizou sobre o fato de ela nomear os objetos e, depois do desenrolar da trama, batizar o cachorro com um nome, o sujeito dois ressaltou sobre a tristeza da velhinha perante a circunstância de seus amigos já terem falecido. Também na segunda resposta podemos ter essa notoriedade sobre a compaixão do aluno com os sentimentos da velhinha, sobretudo através do adjetivo "feliz" atribuído a ela pelo aluno.

Percebemos, através dos comentários escritos desses dois alunos, que eles tiveram duas percepções diferentes a respeito da mesma obra, a qual foi lida por ambos nos mesmos espaço e tempo. Já o sujeito 03, como podemos ver no manuscrito abaixo, deixa explícito a relação de algo da personagem principal da história inclusive consigo:

Fig. 3 - Registros escritos do sujeito 03

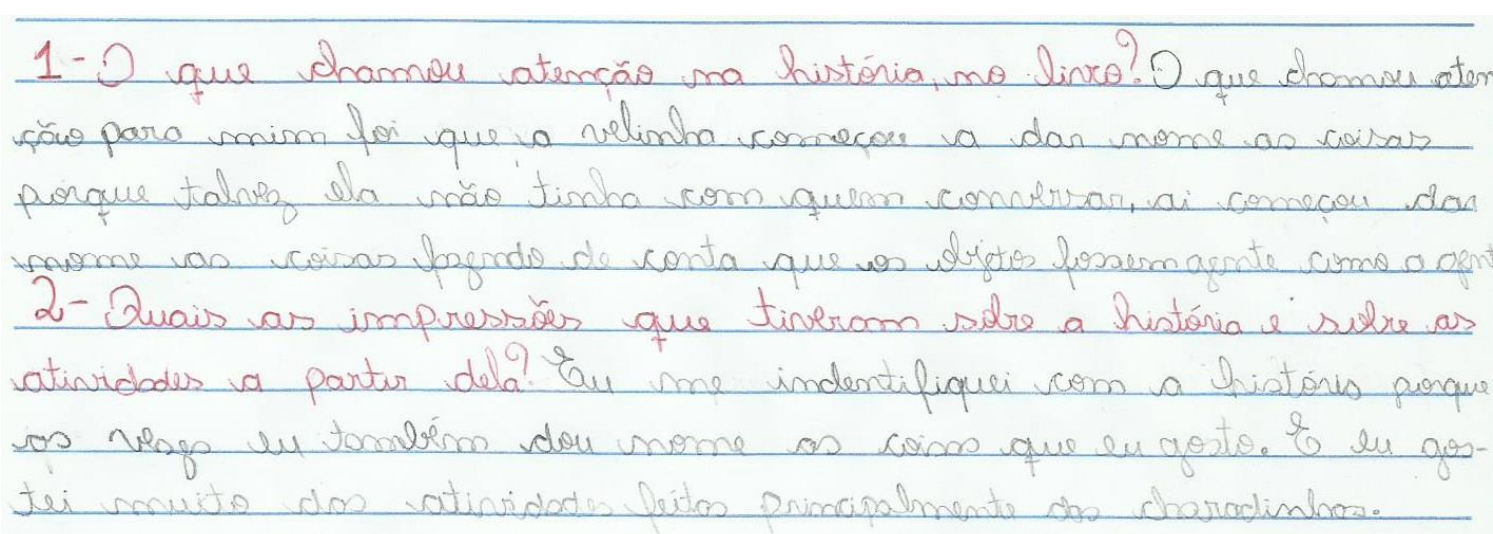

Fonte: digitalização dos manuscritos do sujeito 03 feitos em sala de aula e entregues ao professor.

Como já enfatizamos acima, esse aluno identifica-se com a personagem da história e deixa isso evidenciado em uma de suas respostas quando ressalta que tem o mesmo costume que a velhinha da história, o de por nomes próprios em seres inanimados. $\mathrm{Na}$ INTERLETRAS, ISSN N $N^{\circ}$ 1807-1597. V. 9, Edição número 34. Outubro, 2021/ Março de 2022- p

Dossiê: Educação, infância, diversidade e ensino de língua em contexto complexo. 
primeira resposta, porém, percebemos que esse aluno também se sensibilizou com a história do livro, ressaltando o aspecto da solidão, da falta de ter com quem conversar.

Logo, a leitura da história despertou neste aluno, assim como no sujeito um, o sentimento de compaixão. Julgamos pertinente abordarmos o tom enfático que o aluno sujeito 03 usa para externar sua percepção a respeito dessa solidão. Ele descreve que, na história, a velhinha tratava os objetos como se "fossem gente como a gente". Esse final da primeira resposta, atrelado àquilo que o mesmo aluno escreveu na segunda resposta, permite inferir que ele passava momentos de solidão, recorrendo à estratégia de nomear seres inanimados. Tal processo de personificação diminuiria a solidão, evidenciaria a falta de amigos ou o encontro de amigos onde não se imaginaria. Tais recepções do livro são evidenciadas por outros alunos, e novas são trazidas, como é o caso do sujeito quatro.

Fig. 4 - Registros escritos do sujeito 04

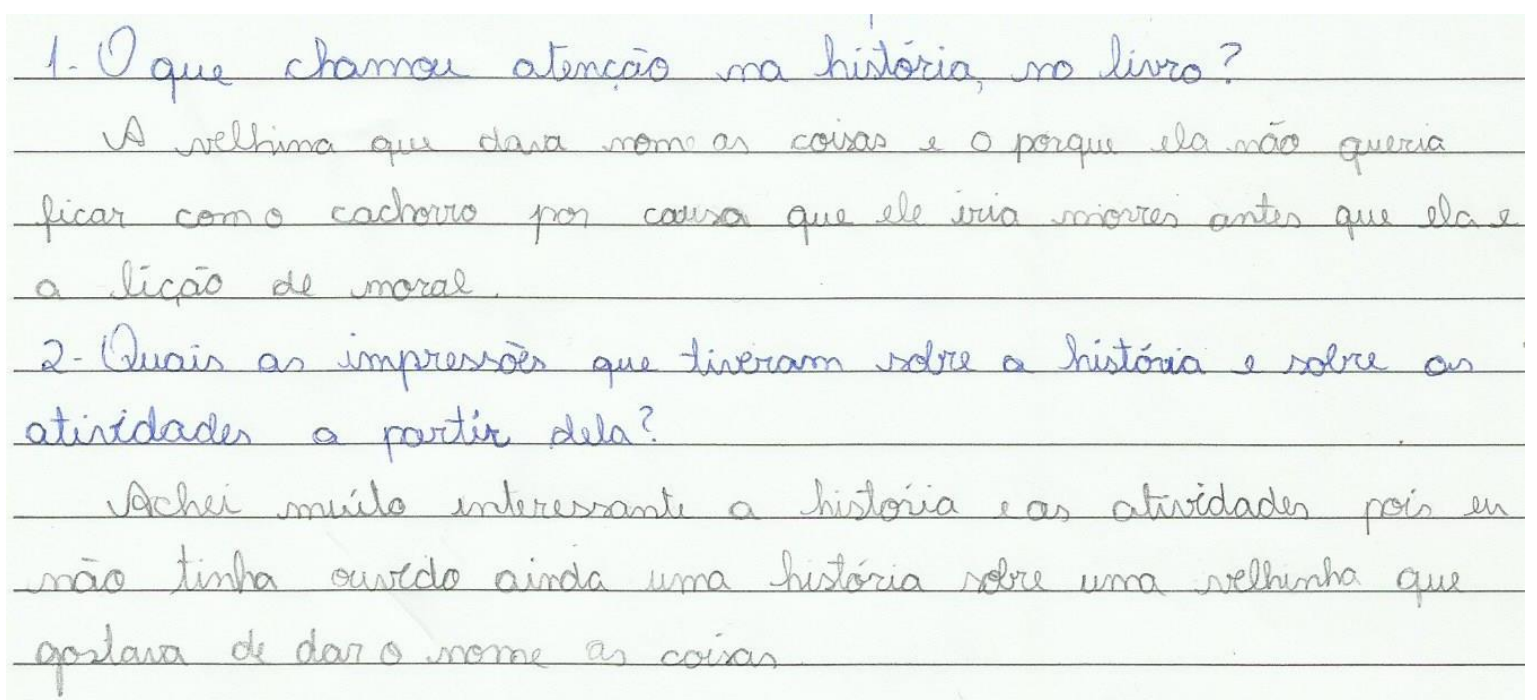

Fonte: digitalização dos manuscritos do sujeito 04 feitos em sala de aula e entregues ao professor.

Como podemos verificar, esse aluno enfatiza sobre a unicidade da história, ou seja, o fato de não conhecer outra história parecida com esta. Além disso, ele ressalta na primeira resposta, assim como alguns demais alunos, sobre a personagem principal e seu costume não convencional na realidade de muitas pessoas. É interessante que esse aluno menciona sobre a lição de moral, mas não descreve qual é, o que talvez outros fizeram sem usar essa expressão.

O fato da não explicitação da moral, porém, não significa que ela não foi compreendida pelo aluno, pois na primeira resposta ele enfatiza sobre a velhinha não querer por nome no cachorro, porque ele é um ser vivo. Em outras palavras, isso já fora enfatizado por outros alunos, o que ratifica que tal aspecto da história é muito relevante e sobressai-se com relação a muitos demais. O sujeito 05 também faz ponderações semelhantes a outras, no entanto, algumas palavras e percepções nos sobressaltaram.

INTERLETRAS, ISSN $N^{\circ}$ 1807-1597. V. 9, Edição número 34. Outubro, 2021/ Março de 2022- p

Dossiê: Educação, infância, diversidade e ensino de língua em contexto complexo. 
Fig. 5 - Registros escritos do sujeito 05

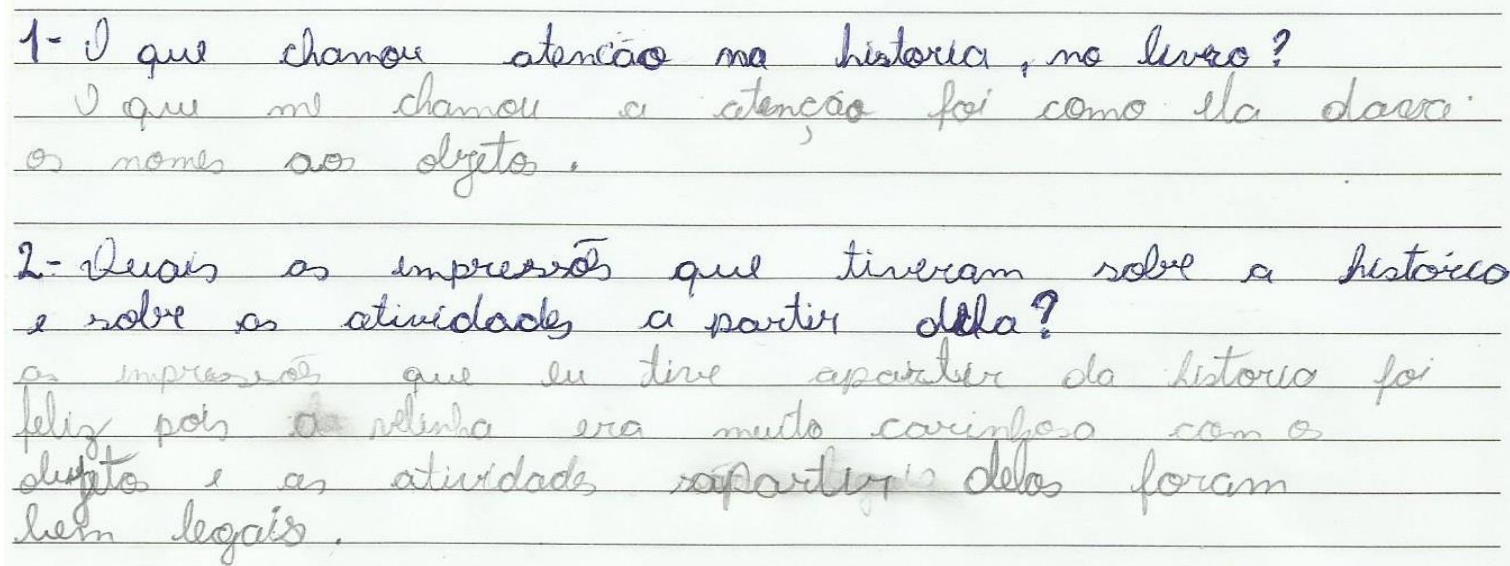

Fonte: digitalização dos manuscritos do sujeito 05 feitos em sala de aula e entregues ao professor.

Primeiramente, não encontramos nenhuma novidade na primeira resposta desse aluno com relação às demais. No entanto, a segunda contém uma palavra que, pelo contexto em que foi usado, é dotado de significação e de um olhar diferenciado, uma percepção diferente das outras. O adjetivo "carinhosa" atribuído pelo aluno à velhinha com relação aos objetos.

Podemos perceber, a partir disso, que o discente identificou na velhinha valores como o zelo por aquilo que ela construiu ao longo da vida. Logo, o adjetivo "carinhosa", nesse contexto, teria sentido valorativo de "cuidadosa". Também nas impressões do sujeito sete há alguns adjetivos interessantes, assim como demais aspectos percebidos e ressaltados pelo aluno.

Fig. 6 - Registros escritos do sujeito 06

1- 1 que chamer atencāo no historia ruo livro?

Me chamou atencä na história o porque a velhinha dova nome as coisas, achei uma história lem autênica e muito lindo

2- invais as impressioss que Hiveram adere a histivia e sobre as patividades apportir dela?

A historia en achei muiti legal, achei g final lem alegre, e achei a história berm escrita (com um testo berm escrito, un tescto com bastaw sentidu le ar atividades en achei muito legal

Fonte: digitalização dos manuscritos do sujeito 06 feitos em sala de aula e entregues ao professor.

INTERLETRAS, ISSN N $N^{\circ}$ 1807-1597. V. 9, Edição número 34. Outubro, 2021/ Março de 2022- p

Dossiê: Educação, infância, diversidade e ensino de língua em contexto complexo. 
Nas respostas desse sujeito, confirmamos que também ele mostrou sensibilização com a velhinha que dava nome aos objetos. No entanto, o interessante da primeira resposta são os adjetivos "autêntica" e "linda" atribuídos à "história". Percebemos, inegavelmente, que esse aluno gostou da história, e percebe que essa história é inigualável, única.

Já na segunda resposta desse sujeito fica declarado um lado mais crítico do aluno, julgando a escrita da história inclusive quanto ao desencadeamento dela. Tudo indica que, para esse aluno, o "bastante sentido" volta-se ao fato de ele concordar com o que foi narrado e que seria algo comum de acontecer na sociedade, como também pode estar voltado para a narração da história, a qual, portanto, é coesa e coerente, pois pouco antes ela escreve sobre o final alegre.

A percepção do desfecho feliz e a identificação do aluno com isso nos remete aos clássicos finais felizes, o que é almejado pela maioria das crianças. Portanto, confirmamos na percepção desse aluno, bem como na dos demais, as impressões e as percepções particulares enfatizadas por cada um.

\section{CONSIDERAÇÕES FINAIS}

A partir da abordagem teórica e das análises com base nos comentários dos alunos a respeito da obra $A$ velhinha que dava nome às coisas pudemos realizar estudos sobre a recepção de uma obra infantil e as percepções desses leitores. Cada uma das crianças evidenciou, por escrito, suas impressões e, assim, destacou o que lhe chamou a atenção e, por que não afirmar, o que lhes proporcionou prazer e comoção durante a leitura da história.

Conforme Iser (1999) já nos informava, o prazer da leitura é algo primordial e está atrelado à estética da obra, bem como ao uso da linguagem e às estratégias usadas pela autora - desde um diminutivo no título, como no caso de "velhinha", até um enredo elaborado com lógica sequencial. Diante dessa gama de possibilidades, cada aluno destacou o que julgou mais interessante e explicitou o que mais lhe impressionou.

Ao analisarmos as percepções dos alunos, percebemos a importância que eles atribuem para o lado de humanização da história. Talvez sem se darem conta e terem compreensão disso, os alunos descreveram a emoção que sentiram ao ler a história. Isso por que ela despertou neles comoção, sensibilização, capacidade de colocarem se no lugar do outro, como um deles explicitou em seu comentário. Dessa forma, percebemos que as crianças já têm em si o senso crítico, que deve ser aprimorado e instigado.

Em linhas gerais, concluímos, sistemática e sinteticamente, que "Ler, apropriar-se dos livros, é reencontrar o eco longínquo de uma voz amada na infância, o apoio de sua presença sensível para atravessar a noite, enfrentar a escuridão e a separação. " (PETIT, 2009, p. 65).

INTERLETRAS, ISSN $N^{\circ}$ 1807-1597. V. 9, Edição número 34. Outubro, 2021/ Março de 2022- p

Dossiê: Educação, infância, diversidade e ensino de língua em contexto complexo. 
Nessa perspectiva, a leitura é um caminho para novos mundos, em que a sensibilização e a correlação do eu com o outro se amplificam desde crianças. Enfim, a leitura é um ato de despertar de amor - amor pelo eu, amor pelo outro - o que precisa ser compreendido e praticado pelos sujeitos de uma sociedade desde a sua infância.

\section{REFERÊNCIAS}

ISER, Wolfgang. O ato da leitura: uma teoria do efeito estético. Tradução de Johannes Kretschmer. Vol. 2. São Paulo: Editora 34, 1999.

JAUSS, Hans Robert. A história da literatura como provocação à teoria literária. São Paulo: Ática, 1994.

PETIT, Michèle. Os jovens e a leitura: uma nova perspectiva. Tradução de Celina Olga de Souza. São Paulo: Ed. 34, 2008.

RYLANT, Cynthia. A velhinha que dava nome às coisas. Traduzido por Gilda de Aquino. Disponível em: http://jejepedagoga.blogspot.com/2015/07/livro-velinha-quedava-nome-as-coisas.html. Acessado em 02 de abril de 2018.

ZILBERMAN, Regina. Estética da recepção e história da literatura. São Paulo: Ática, 1989.

*Airton Pott. Doutorando em letras pela Universidade de Passo Fundo. ORCID: https://orcid.org/00000002-9809-1320.

**Ivânia Campigotto Aquino. Possui pós-doutorado em Letras - Estudos de Literatura pela Universidade Federal do Rio Grande do Sul. Atualmente, é professora Titular III da Universidade de Passo Fundo, atuando no curso de Letras e no Programa de Pós-Graduação em Letras. ORCID: https://orcid.org/0000$\underline{0001-9221-3473}$. 